Original Article

\title{
Breeding and reproductive behaviour of the neo-tropical opossum, Didelphis marsupialis insularis, Allen 1902 under captive conditions
}

\author{
Reprodução e comportamento reprodutivo do gambá neotropical, Didelphis marsupialis \\ insularis, Allen 1902, em condições de cativeiro \\ L. Tardieu ${ }^{\text {** (D) }}$ and G. W. Garcia ${ }^{\mathrm{a}}$ (1) \\ ${ }^{a}$ The University of the West Indies, Faculty of Food and Agriculture, Department of Food Production, The Open Tropical Forage-Animal Production \\ Laboratory, St. Augustine, Trinidad and Tobago
}

\begin{abstract}
Developing a captive breeding system for the widely hunted Caribbean species of opossum Didelphis marsupialis insularis can greatly aide in the management and conservation of this species in the neo-tropics. Although this species possesses ideal traits for captive breeding in this region (tolerance to high heat and humidity, high reproductive rate, and resistance to disease), challenges due to its aggressive behaviour and limited information on its breeding behaviour have prevented a system from being developed for this species. The present study describes a breeding system, and the reproductive behaviour of this species under captive conditions. Six ( 1 male; 5 females) adult opossums were maintained and managed for breeding over a ten (10) month period. Pouch litter sizes averaged $5 \pm 2.5$ with a range of 2 to 8 . Gestation length was found to be $13.25 \pm 0.96$ days and 4 litters $(n=23)$ were successfully weaned at 11-13 weeks. It was found that the male D. m. insularis exhibits behaviours of interest that can serve as indicators for receptivity of the female, and overall, that this species can be successfully reared and bred under captive conditions in the neo-tropics.
\end{abstract}

Keywords: Didelphis marsupialis insularis, captive breeding, marsupial, opossum, reproduction.

\begin{abstract}
Resumo
O desenvolvimento de um sistema de criação em cativeiro para as espécies de gambá do Caribe amplamente caçadas, Didelphis marsupialis insularis, pode auxiliar bastante no manejo e conservação dessa espécie nos neotrópicos. Embora essa espécie possua características ideais para a criação em cativeiro nessa região (tolerância a altas temperaturas e umidade, alta taxa de reprodução e resistência a doenças), alguns fatores, como o seu comportamento agressivo e informações limitadas sobre seu comportamento reprodutivo, impediram o desenvolvimento de um sistema para D. m. insularis. O presente estudo descreve um sistema de criação e o comportamento reprodutivo dessa espécie em condições de cativeiro. Seis gambás adultos ( 1 macho e 5 fêmeas) foram mantidos para reprodução durante um período de 10 meses. 0 tamanho da ninhada em bolsa foi em média de $5 \pm 2,5$ com um intervalo de 2 a 8 . A duração da gestação foi de $13,25 \pm 0,96$ dias, e 4 ninhadas $(n=23)$ foram desmamadas com sucesso de 11 a 13 semanas. Verificou-se que o macho $D$. $m$. insularis exibe comportamentos de interesse que podem servir como indicadores de receptividade da fêmea, e, em geral, essa espécie pode ser criada com sucesso em condições de cativeiro nos neotrópicos.
\end{abstract}

Palavras-chave: Didelphis marsupialis insularis, criação em cativeiro, marsupial, gambá, reprodução.

\section{Introduction}

Given the increase in hunting pressure on wildlife in developing neo-tropical island nations, captive wildlife production systems have been experiencing increasing popularity in these regions (Brooks et al. 2010; Bulte and Damania, 2005; Hoffman and Cawthorn, 2012; Nogueira and Nogueira-Filho, 2011). Non-domesticated species like the agouti/cutia (Dasyprocta leporina, Dasyprocta spp.) and the lappe (Cuniculus paca/Agouti

paca) (Brown-Uddenberg et al., 2004), have all been successfully studied and bred under captive conditions using production systems. These captive wildlife systems have proven to be effective at meeting their required objectives that include, serving as a conservation and population management tool and further functioning as a form of sustainable utilization of neo-tropical species in the region. 
Didelphis marsupialis insularis is the popularly hunted opossum species that inhabits the smaller Caribbean islands of Trinidad and Tobago and the Lesser Antilles (Allen, 1902). The neo-tropical opossums' high reproductive rate, ability to tolerate tropical climates and a wide, omnivorous diet has led it to being identified as an ideal candidate for captive animal breeding in the region (Tardieu et al., 2017). However, this species also poses special challenges that hinder the development of a captive breeding system, namely its aggressive nature and the lack of information available on its breeding behaviours. To date, there have been no effective captive breeding nor captive management systems recorded for this species in the Caribbean.

As many studies have highlighted differences even among closely related species, in Didelphis (Caceres, 2005; Tardieu et al., 2017, 2019b), the utilization of captive breeding systems conducted for related Didelphis species may not be widely applicable. Therefore, studies are required on this particular subspecies to determine captive reproduction management in the neo-tropical region.

The overall aim of this research was to trial a captive reproduction system for $D$. marsupialis insularis on the neo-tropical island of Trinidad and Tobago, and further to note the reproductive behaviours of this species under these conditions. If successful, it could eventually serve as a useful conservation tool and further be used for animal production in the Caribbean region.

The specific objectives of this study were (1) to develop and test a captive housing and management system for the breeding of D. m. insularis in the neo-tropics and (2) to document the reproductive parameters and behaviours of $D$. m. insularis in captivity.

\section{Materials and Methods}

\subsection{Housing and Caging design}

The study site was located in Chaguaramas, Trinidad and Tobago $\left(10.6825^{\circ} \mathrm{N}, 61.6341^{\circ} \mathrm{W}\right)$ and the breeding system was run for a 10 month period from January 2018 to October 2018. The animal caging system was housed within an indoor compound with natural lighting, using a 12 hour light and 12 hour dark cycle, supplemented by fluorescent bulbs, electricity and water. Cages were constructed to hold adult opossums individually and the custom caging design was based on the 'Single Corridor housing system' described by Tardieu and Garcia (2018) and illustrated in Figures 1, 2 and 3.

The caging system was composed of six cages and possessed the following dimensions; total caging unit (L $2.44 \mathrm{~m} \mathrm{x} \mathrm{W} 1.04 \mathrm{~m} \times \mathrm{H} 0.38 \mathrm{~m}$ ), male cage (L $2.44 \mathrm{~m}$ x W $0.41 \mathrm{~m} \mathrm{x} \mathrm{H} 0.38 \mathrm{~m}$ ); and the female cages ( $\mathrm{L} 0.67 \mathrm{~m}$ x W 0.45 m x H 0.38 m). Caging dimensions were based on Jurgelski Junior et al. (1974) laboratory cage designs. Finally, the access door for the male to the female units were each $\mathrm{H} 0.38 \mathrm{~m}$ x W $0.4 \mathrm{~m}$ (Figures 1 and 2).

Fine wire mesh (approximately $0.03 \mathrm{~m}$ x $0.015 \mathrm{~m}$ ) was utilized for the entire enclosure to achieve the following 1)

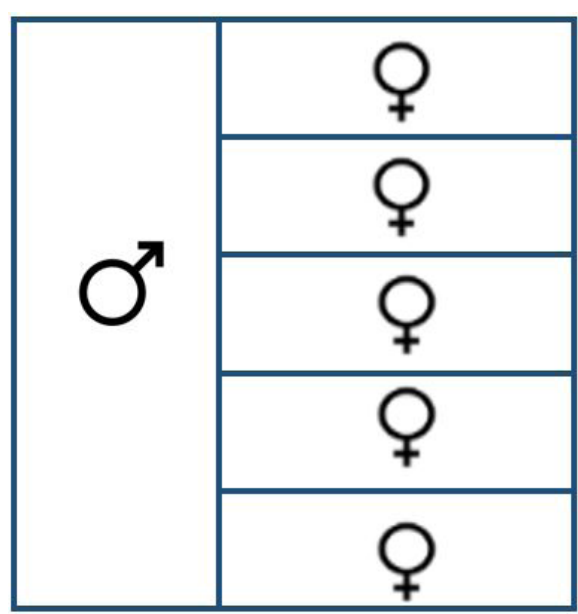

Figure 1. Design and layout of Adult Units using a Single Corridor Layout. Source: Tardieu and Garcia, 2018).

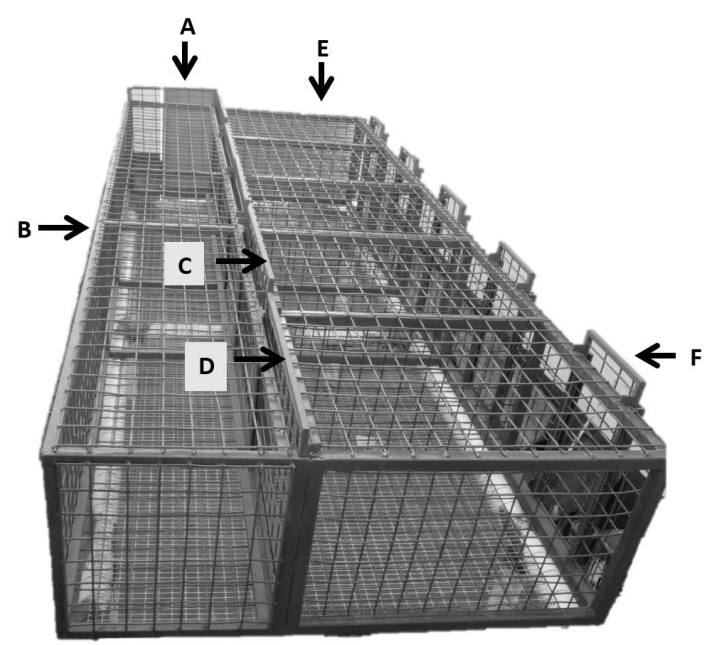

Figure 2. Photo of opossum breeding unit showing - (A) Human Access panel to Male; (B) Male Cage; (C \& D) Male Access panels to females; (E) Female Cage; (F) Human Access panel to Female.

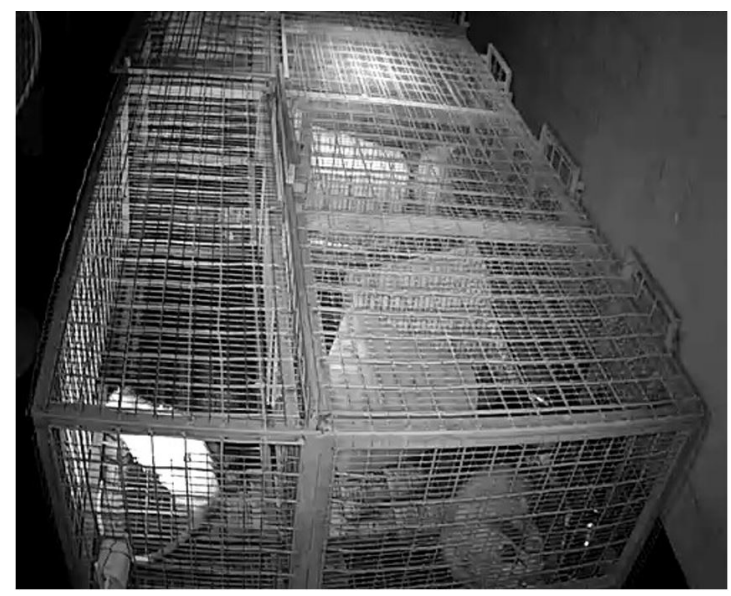

Figure 3. Photo of opossum breeding unit showing view from top of enclosure. 
prevent the damage and slippage of opossum feet through the caging unit, 2) prevent any aggression and harm to the animals that might occur from tails or limbs slipping though the wire holes to the neighbouring cages and finally 3 ) to reduce access to pest species like rodents.

In order to observe the behaviour of the adults in the evening and night-time periods, an outdoor camera system with three units was utilized $\left(\mathrm{Zmodo}^{\mathrm{TM}} 720 \mathrm{HD}\right.$ Outdoor WiFi IP Camera). Camera units were placed in fixed locations and positioned to offer the following views; Camera 1: Bird's eye view of the entire unit; Camera 2: Inside view of the male unit; Camera 3: (Roving camera) view of any one female that was being bred. Behavioural observations were conducted using an ad libitum sampling method, using an interval type of data recording. Each animal enclosure unit was furnished with a food and water bowl and a 'bucket-type' den as described by Tardieu and Garcia (2018).

This research has received ethical approval from The University of the West Indies, St. Augustine, Trinidad and Tobago, Campus Research Ethics Committee Ref CEC491/03/18

\subsection{Animal collection and management}

Didelphis marsupialis insularis adults were wild-caught from various locations in the Republic of Trinidad and Tobago and were captive held separately for at least three days before being introduced into the breeding system (Figure 4). Opossums were weighed and possessed an average body mass of $2.7 \pm 0.8 \mathrm{~kg}$ and were between one to three years old, based on body condition and teeth wear (Ramírez and Osorio, 2014). A total of six ( $n=7)$ animals were utilized for this trial study; females $(n=6)$ and males $(n=1)$. The experimental system held during breeding trials, a total of 6 adults (5F:1M). All females were identified as being in reproductive condition (Table 1). Water was offered ad libitum and the diet consisted of commercial based dog chow, seasonal fruits and vegetables and meat/protein items (e.g. fish, chicken parts). The diet was based on reported diets fed to captive specimens in rehabilitation facilities in the neo-tropics (W. Rollock, personal communication, 2017). Food was offered once daily, between 17:00-18:00h.

\subsection{Reproduction/breeding management}

The male behaviour was closely observed for behaviours of interest. Using the camera system, observations were conducted following daily feeding and cleaning procedures, to determine if the female was in oestrus, or receptive for breeding based on the findings of Tardieu et al. (2019a). Once interest was detected by the male, the male would be allowed access to the female via the removal of the access panel (Figure 2 ). The breeding pair would be closely monitored and the male freely allowed access to the female,

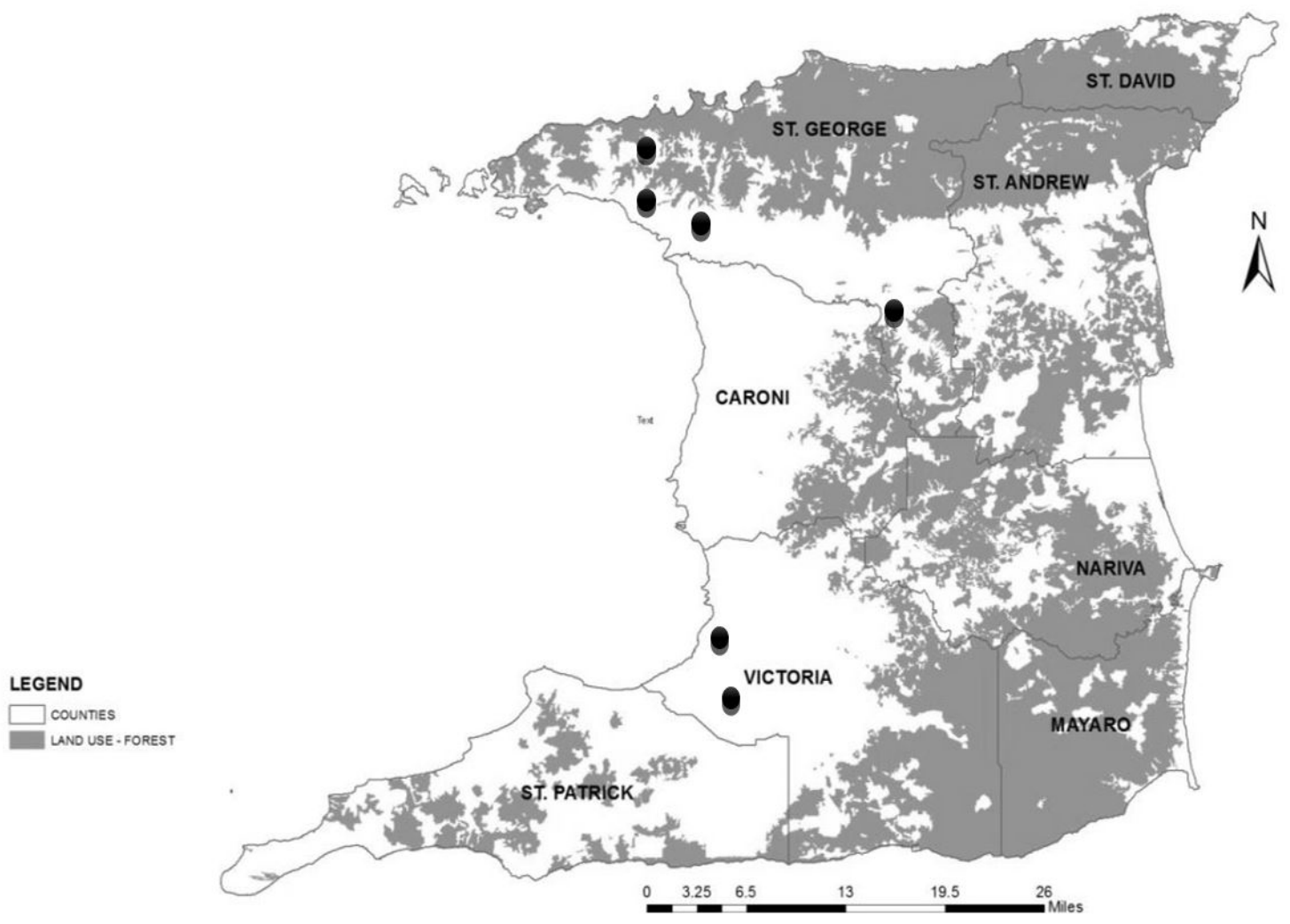

Figure 4. Map of Trinidad and Tobago showing the locations where the adult D. m. insularis were trapped. 
Table 1. Detailed descriptions of individual adult opossums (D. m. insularis).

\begin{tabular}{cccccc}
\hline Specimen & Sex & Weight $(\mathbf{k g})$ & $\begin{array}{c}\text { Approximate age } \\
\text { (years) }\end{array}$ & $\begin{array}{c}\text { "Reproductive } \\
\text { condition upon } \\
\text { capture }\end{array}$ & $\begin{array}{c}\text { Number of } \\
\text { Litters** }\end{array}$ \\
\hline 1 & F & 3.9 & 3 & Yes & 0 \\
2 & F & 1.8 & 1 & No & 1 \\
3 & F & 3.2 & 1 & No & 2 \\
4 & F & 2.0 & 1 & No & 1 \\
5 & F & 2.7 & 1 & Yes & 2 \\
6 & F & - & 1 & Yes & 1 \\
7 & M & 2.3 & 2 & - & - \\
\hline
\end{tabular}

*Reproductive condition indicates whether signs of reproductive events occurred these include distended marsupium pouch, noticeable nipples and yellowing of pouch; **Number of litters that female produced. $\mathrm{F}=$ Female and $\mathrm{M}=$ Male.

Table 2. Observed reproductive behaviours of $D$. marsupialis insularis in captivity.

\begin{tabular}{llc}
\hline \multicolumn{1}{c}{ Behaviour } & \multicolumn{1}{c}{ Definition } & Observation Point \\
\hline Male visits to Female Door & Male spends $>$ 1 minute by female enclosure in front of wire mesh door & Pre-pairing \\
Genital Marking & $\begin{array}{l}\text { Male scent marks, rubbing genitalia and or urinating on wire mesh directly } \\
\text { in front of female door }\end{array}$ & Pre-pairing \\
Clicking & Male exhibits a metallic 'clicking' type vocalization & Pre-pairing \\
Attempted mount & Male bites female by neck, grabs with forepaws and attempts to overpower & Intra-pairing \\
Copulation & Male mounts female, fall to the side and achieves intromission & Intra-pairing \\
Snapping & Attempting to bite a conspecific & Pre-pairing and \\
& & Intra-pairing \\
Chasing & Rapidly pursuing a conspecific & Intra-pairing \\
Aggression & Includes either or all of the following: snapping of a conspecific, displaying & Pre-pairing and \\
& of teeth, hissing, chasing & Intra-pairing \\
Injury & Bleeding or injury from a scratch, tear or bite & Intra-pairing \\
\hline
\end{tabular}

until either mating had been observed or a given period of time (4-5 days) with no mating had elapsed. The access door to the female would then be closed and the male and female separated into their individual cages.

After mating the female would be monitored for a period of 11-14 days for signs of parturition. For this study observation of unsuccessful newborns (newborns that did not make it into the pouch to attach to a nipple) on the cage flooring was utilized as signs of parturition. Didelphis are reported as producing more young than they can support (Krause and Krause 2006) resulting in many newborns not surviving to the next phase of development. A week following the 11-14 day parturition period, the female would then be restrained and her pouch checked for suckling young. After a period of 12-13 weeks, (time period based on by Tardieu et al. (2019a) young opossums would be weaned (removed) from the female to allow the female to begin cycling again. Descriptive statistics were used and means were provided through the manuscript when necessary.

\section{Results}

\subsection{Reproductive behaviours}

Male behaviour provided fairly reliable indicators of female receptivity. These included three noteworthy actions of interest; (1) increased interest in the form of time spent near to the female's enclosure door, (2) marking and (3) clicking vocalizations similarly reported by Tardieu et al. (2019a) these reproductive behaviours are detailed in Table 2.

\subsection{Reproductive parameters}

A total of five mating episodes with four parturitions were documented over the ten month period. Four litters were successfully weaned from females over this period.

Mating was observed to occur at two separate time periods; late evening (20:00h) or early morning (5:00-6:00h) and the male took a mean of $2.8 \pm 1.3$ days to mate with a female after being allowed access to a female. It was found that two females produced multiple litters during the observation period (that demonstrated the repeatability of the mating protocol); however, only one female had both litters survive to weaning age. Important reproductive parameters of this species that were obtained from this study are summarised in Table 3.

\section{Discussion}

The results from this study have shown that the neotropical subspecies, D. marsupialis insularis can be captive bred in the neo-tropics and generated reproductive parameters and breeding observations. Based on these 
Table 3. Reproductive parameters of the opossum (D. m. insularis) in Trinidad and Tobago under captive conditions.

\begin{tabular}{lccccc}
\hline \multicolumn{1}{c}{ Reproductive Parameters } & Mean & SD & Min & Max & n \\
\hline Length of gestation (days) & 13 & 0.96 & 12 & 14 & 5 \\
Litter size (at birth) & 19 & 12.99 & 2 & 31 & 25 \\
Litter size (at weaning) & 5 & 2.5 & 2 & - & - \\
Weaning Age (weeks) & $11-13$ & - & 72.83 & 102.75 & 25 \\
Weaning weight (g) & 85.98 & 13.03 & 10 & 22 & 25 \\
Interval between weaning and mating (days) & 16 & 8.49 & 4 & 8 & 25 \\
Survival post-weaning & 6 & 1.91 & & & 25 \\
\hline
\end{tabular}

$\mathrm{SD}=$ Standard Deviation, $\mathrm{n}=$ sample size .

findings, an adult reproductive female $D$. marsupialis insularis opossum has the potential to produce at least two litters, with approximately five to eight young per year. This was similarly found to be the case with $D$. albiventris which also has been observed to be capable of producing two generations from one reproductive season (Astúa and Geise, 2006).

Determination of receptivity of the female for breeding is vital for the reproduction of any species. Previous methods of oestrus detection for Didelphis opossums relied solely on laboratory tests. One laboratory method, used by Jurgelski Junior and Porter (1974), provided much detail on how to determine receptivity of the female, but involved laboratory conditions and relatively frequent handling of the female. However, outside of the laboratory this method may be impractical, too invasive and negatively affect the behaviour of the animals thus reducing productivity.

Alternatively a technique using reproductive behaviour analysis, as described by Silva et al. (2017) may be more appropriate for this application. This technique is supported by observations from local wildlife carers, who have indicated that males gave behavioural cues, such as audio and visual signs, when the female was receptive (W. Rollock, personal communication, 2017). Ryser (1992) suggested that females were able to advertise their breeding status by means of chemical signals, and that although males would be able to gather information from these signals, regarding the time to oestrus, they may not become aware of oestrus more than one or two days in advance.

Behavioural analysis as a means of oestrus detection, was supported by the observations made in this study, as it was found that given proper observation, the cues of behavioural interest shown by the male, did serve as fairly accurate detectors of oestrus.

The five mating episodes that resulted in four parturitions in this study were solely based on cues detected by observing the male and provide support that this species can be bred in captivity using the behavioural cues of the male and not relying on the cues of the female, as has been the practice with most domesticated animals (Herren, 2012).

The one mating episode between the male and female that proved to be unsuccessful may have been due to the male misreading the signals of the female or that the female may have been a first time breeder. It was observed that mating under captive conditions can take a physical toll on the male who up until the brief mating act, was found to be aggressively chased and snapped at by the female. The breeding male in this study received minor and sometimes major injuries particularly to his extremities i.e. tail. This is supported by Fritz (1971) who reported damage to the tail or tail injuries with the opossum.

Copulations were found to occur either in the late evening (8pm) or early morning (5-6am) which do not agree with those observations of Tyndale and Biscoe (Tyndale-Biscoe, 2005). These authors cited between midnight and dawn as the period when fertile copulations usually occurred. This inconsistency may have been a result of the different Didelphis species studied, as Tyndale's report was conducted on wild North American opossums (D. virginiana).

\subsection{Weaning age}

Young opossums have been observed to cannibalize the mother if allowed to remain with her for too long. Reports of damage to the tail, ears and skin of the female by her own young, have been made for $D$. virginiana (Jurgelski Junior and Porter, 1974), while cannibalization among newly weaned litter mates has also been recorded in Didelphis species housed in the same cage (McManus 1970).

Weaning age for $D$. virginiana young was recommended to be approximately 90-100 days (13-14weeks) (Jurgelski Junior and Porter, 1974). While for D. aurita weaning occurred at 143 days (20 weeks) (Gentile and Cerqueira, 1995 ) and at 3.5 months (14 weeks) for D. albiventris (Regidor and Gorostiague, 1996). Using reported weaning ages from wild caught individuals cared for in neo-tropical rehabilitation clinics (W. Rollock, personal communication, 2017), young from four litters were successfully weaned at about 77-91days (11-13 weeks) which was closer to the range quoted for $D$. virginiana species.

Weaning age is important for animal reproduction, as it determines the productivity of the species under captive conditions. It also can be used for the evaluation of population dynamics, the onset of reproduction, reproductive potential, and time between generations all 
being important parameters for ecological, conservation and evolutionary biology studies. Moreover, correct estimates of female reproductive capacity allows for a more precise definition of several parameters (Astúa and Geise, 2006).

Re-breeding or time between successive litters is another important reproductive parameter for animal reproduction. Under laboratory captive conditions Jurgelski Junior and Porter (1974) found that 2-8 days after weaning the female re-enters oestrus and so can be mated, while Cutts et al. (1978) reports 20 days for one female. Reynolds (1952) and Green et al. (1996) studies have found that removal of young will usually lead the female to a return to oestrus within 7-14 days. The study herein observed a period of approximately 16 days and while only two re-matings were initiated, both resulted in parturitions. However, of the two parturitions only one female maintained young successfully to weaning age.

Cutts et al. (1978) have also noted that non-virgin, wild caught females were more apt to rebreed and become pregnant under captive conditions. Further that the greatest number of failures to become pregnant occurred with wild caught, virgin females who Cutts et al. (1978) explained may just not be naturally vigorous breeders. This agrees with our findings as one of the rebred females had previously carried young and was able to successfully wean her litter. While the other female did not appear to have carried pouch young when she was caught and when rebred, though able to get pregnant, was unable to carry to weaning age, as the newborns were unsuccessful at attaching to nipples.

In conclusion, this study shows that the neo-tropical opossum D. m. insularis can be captive bred in the neotropics. Furthermore, behavioural cues can be used to determine the receptivity of the female for mating. Finally, it provides evidence and lends support to the development and use of captive breeding systems for conservation and production of 'non-domesticated' wildlife species like the neo-tropical opossum in the Caribbean.

\section{Acknowledgements}

The authors would like to thank Ms. Wendy Rollock for her support and assistance with this research. We are also grateful to Mr. Martin Wyow for his excellent construction of the experimental caging system. This work was supported by the University of the West Indies, School for Graduate Studies and Research, Campus Research and Publication Fund (CRP.5.FEB18.37 2018).

\section{References}

ALLEN, J.A.A., 1902. preliminary study of the South American opossums of the genus Didelphis. Bulletin of the American Museum of Natural History, vol. 16, pp. 249-279.

ASTÚA, D. and GEISE, L., 2006. Early reproductive onset in the white-eared opossum, Didelphis albiventris Lund, 1840 (Didelphimorphia, Didelphidae). Mammalian Biology, vol. 71, no. 5, pp. 299-303. http://dx.doi.org/10.1016/j.mambio.2006.03.003.
BROOKS, E.G.E., ROBERTON, S.I. and BELL, D.J., 2010. The conservation impact of commercial wildlife farming of porcupines in Vietnam. Biological Conservation, vol. 143, no. 11, pp. 2808-2814. http:// dx.doi.org/10.1016/j.biocon.2010.07.030.

BROWN-UDDENBERG, R.C., GARCIA, G.W., BAPTISTE, Q.S., COUNAND, T., ADOGWA, A.O. and SAMPSON, T., 2004. The Agouti [Dasyprocta leporina, D. aguti] Booklet and Producers' Manual. Trinidad and Tobago: GWG Publications.

BULTE, E.H. and DAMANIA, R., 2005. An economic assessment of wildlife farming and conservation. Conservation Biology, vol. 19, no. 4, pp. 1222-1233. http://dx.doi.org/10.1111/j.15231739.2005.003413.x.

CACERES, N.C., 2005. Comparative lengths of digestive tracts of seven Didelphis marsupials (Mammalia) in relation to diet. Revista Brasileira de Zoologia, vol. 22, no. 1, pp. 181-185. http:// dx.doi.org/10.1590/S0101-81752005000100021.

CUTTS, J.H., KRAUSE, W.J. and LEESON, C.R., 1978. General observations on the growth and development of the young pouch opossum, Didelphis virginiana. Biology of the Neonate, vol. 33, no. 5-6, pp. 264-272. http://dx.doi.org/10.1159/000241082. PMid:567497.

FRITZ, H.I., 1971. Maintenance of the Common opossum in captivity. International Zoo Yearbook, vol. 11, no. 1, pp. 46-49. http://dx.doi. org/10.1111/j.1748-1090.1971.tb01843.x.

GENTILE, R. and R. CERQUEIRA., 1995. Movement patterns of five species of small mammals in a Brazilian restinga. Journal of Tropical Ecology, vol. 11, pp. 671-677.

GREEN, B., KRAUSE, W. and NEWGRAIN, K., 1996. Milk composition in the North American opossum (Didelphis virginiana). Comparative Biochemistry and Physiology. Part B, Biochemistry \& Molecular Biology, vol. 113, no. 3, pp. 619623. http://dx.doi.org/10.1016/0305-0491(95)02034-9. PMid:8829811.

HERREN, R.V., 2012. Animal behavior. In R.V. HERREN. Science of animal agriculture. Delmar: Cengage Learning, pp. 202-217.

HOFFMAN, L.C. and CAWTHORN, D.M., 2012. What is the role and contribution of meat from wildlife in providing high quality protein for consumption? Animal Frontiers, vol. 2, no. 4, pp. 40-53. http://dx.doi.org/10.2527/af.2012-0061.

JURGELSKI JUNIOR, W.J. and PORTER, M.E., 1974. The opossum (Didelphis virginiana Kerr) as a biomedical model. III. Breeding the opossum in captivity: methods. Laboratory Animal Science, vol. 24, no. 2, pp. 412-425. PMid:4362895.

JURGELSKI JUNIOR, W.J., FORSYTHE, W., DAHL, D., THOMAS, L.D., MOORE, J.A., KOTIN, P., FALK, H.L. and VOGEL, F.S., 1974. The opossum (Didelphis virginiana Kerr) as a biomedical model. II. Breeding the Opossum in Captivity: facility Design. Laboratory Animal Science, vol. 24, no. 2, pp. 404-411. PMid:4362894.

KRAUSE, W.J. and KRAUSE, W.A., 2006. The opossum: it's Amazing story. Columbia: University of Missouri.

MCMANUS, J.J., 1970. Behaviour of captive opossums, Didelphis marsupialis virginiana. American Midland Naturalist, vol. 84, no. 1, pp. 144-169. http://dx.doi.org/10.2307/2423733.

NOGUEIRA, S.S.C. and NOGUEIRA-FILHO, S.R.L.G., 2011. Wildlife farming: an alternative to unsustainable hunting and deforestation in Neotropical forests? Biodiversity and Conservation, vol. 20, no. 7, pp. 1385-1397. http://dx.doi. org/10.1007/s10531-011-0047-7.

RAMÍREZ, G.F., OSORIO, J.H., 2014. Identificación de helmintos en zarigüeyas (Didelphis marsupialis) en el Suroccidente Colombiano. Biosalud, vol. 13, pp.37-44. 
REGIDOR, H.A. and GOROSTIAGUE, M., 1996. Reproduction in the Whiteeared opossum (Didelphis albiventris) under temperate conditions in Argentina. Studies on Neotropical Fauna and Environment, vol. 31, no. 3-4, pp. 133-136. http://dx.doi.org/10.1076/snfe.31.3.133.13338.

REYNOLDS, H.C., 1952. Studies on reproduction in the opossum, Didelphis virginiana virginiana. University of California Publications in Zoology, vol. 52, pp. 223-283.

RYSER, J., 1992. The mating system and male mating success of the Virginia opossum (Didelphis virginiana) in Florida. Journal of Zoology, vol. 228, no. 1, pp. 127-139. http://dx.doi. org/10.1111/j.1469-7998.1992.tb04437.x.

SILVA, A.R., MOREIRA, N., PEREIRA, A.F., PEIXOTO, G.C.X., MAIA, K.M., CAMPOS, L.B. and BORGES, A.A., 2017. Estrus cycle monitoring in wild mammals: challenges and perspectives. In: R.P. CARREIRA, ed. Theriogenology. London: IntechOpen. http://dx.doi.org/10.5772/intechopen.69444.

TARDIEU, L. and GARCIA, G.W., 2018. Didelphis species, neotropical animals with the potential for intensive production Part 3: theoretical models of a semi-intensive housing facility for the neo-tropical opossum (Didelphis marsupialis insularis,
Allen, 1902). Tropical Agriculture (St Augistine), vol. 95, no. 4, pp. 350-368.

TARDIEU, L., ADOGWA, A.O. and GARCIA, G.W., 2017. Didelphis species, neo-tropical animals with the potential for intensive production: Part 1 Review of taxonomy, natural history, general biology, animal behaviour, and nutrition. Tropical Agriculture (St Augistine), vol. 94, no. 2, pp. 157-174.

TARDIEU, L., ROLLOCK, W. and GARCIA, G.W., 2019a. Wildlife rehabilitation: a case study of the neo-tropical, opossum Didelphis marsupialis insularis, Allen 1902. Brazilian Journal of Biology = Revista Brasileira de Biologia, vol. 80, no. 3, pp. 529534. https://doi.org/10.1590/1519-6984.214757.

TARDIEU, L., SUNDARAM, V., ADOGWA, A.O. and GARCIA, G.W., 2019b. Anatomy and histology of the gastrointestinal tract of the neo-tropical opossum (Didelphis marsupialis insularis, Allen 1902). Acta Zoologica, vol. 101, no. 4, pp. 384-391. Acta Zoologica, vol. 101, no. 4, pp. 384-391. http://dx.doi.org/10.1111/ azo.12306.

TYNDALE-BISCOE, H., 2005. Life of Marsupials. Australia: CSIRO. http://dx.doi.org/10.1071/9780643092204. 